\title{
Comparison of Pain in the Kocher and Midline Incisions in Patients with Post Cholecystectomy
}

\author{
Agus Yulianto, Agus Raharjo, Untung Alifianto, RTH. Supraptomo
}

Department of Surgery RSDM / Universitas Sebelas Maret Surakarta

\section{ABSTRACT}

Background: Incision techniques that are often used in cholecystectomy laparotomy are the Kocher incision and midline incision. This study was carried out to compare the pain in the Kocher's incision and midline incision in patients with postoperative cholecystectomy laparotomy.

Subjects and Method: : This study was an observational randomized controlled trial double sampling study conducted at the Department of Surgery Dr. Moewardi Hospital Surakarta in October 2018 to February 2019. The sample of this study was 30 patients aged 18-65 years old who were diagnosed with symptomatic cholelithiasis based on clinical, laboratory, and radiological tests. The samples were selected by simple random sampling. The dependent variable of this study was the pain. The independent variables were the Kocher and midline incision techniques. The pain was measured on a 24-hour postopera- tive VAS scale, range 1-10. Data were analyzed by t-test.

Results: There was no significant difference in pain level between the Kocher group (Mean= 2.33; $\mathrm{SD}=0.72$ ) and the midline group (Mean= 2.20; $\mathrm{SD}=0.97$ ) with $\mathrm{p}=0.192$.

Conclusion: There is no difference in pain level due to the Kocher incision technique and the midline incision technique.

Keywords: pain, incision, kocher, midline, cholecystectomy

\section{Correspondence:}

RTH. Supraptomo. Anesthesia dan Intensive Therapy Department Dr. Moewardi Hospital, Surakarta. Jl. Kolonel Sutarto 132 Jebres, Surakarta, Central Java 57126. Email: ekasatrio@gmail.com. Mobile: 081229229567

Cite this as:

Yulianto A, Raharjo A, Alifianto U, Supraptomo RTH (2020). Comparison of Pain in the Kocher and Midline Incisions in Patients with Post Cholecystectomy. Indones J Med. 05(03): 240-245. https://doi.org/10.26911/theijmed.2020.05.03.09.

(F) ID Indonesian Journal of Medicine is licensed under a Creative Commons cc)

BACKGROUND
Cholelithiasis is a formless crystal or material
which is formed in gallbladder. The composi-
tions of cholelithiasis are a mixture of choles-
terol, bile pigment, calcium, and inorganic
matrix.

A more severe complication is cholecystitis which occurs due to an obstruction within bile duct (by stones in the bile duct/choledocholithiasis) and sometimes followed by cholangitis infection and cholelithiasis pancreatitis. Ultrasonography is usually used to diagnose the disease. Cholecystectomy surgical therapy is required if cholelithiasis gene- rates symptoms or complications (Keshav et al., 2015).

Biliary colic is a specific clinical symptom to diagnose cholecystitis disease. Medical imagining methods that can be used to diagnose cholecystitis are USG, ERCP, CTScan, MRI, or MRCP. It has become an agreement that asymptomatic cholelithiasis does not require a therapy even for prophylactic purposes. Cholecystectomy becomes the main therapy for symptomatic cholelithiasis (Parmar et al., 2015). Cholecystectomy is the definitive therapy for patients with symptomatic cholelithiasis. There are some incision techniques in cholecystectomy laparoto- 
my namely Kocher incision and midline incision (Patnalk, Singla and Bansal, 2001)

This study was carried out to compare the pain in the Kocher and midline incisions in patients with postoperative cholecystectomy laparotomy.

\section{SUBJECTS AND METHOD}

\section{Study Design}

This study was an observational randomized controlled trial double sampling study. It was conducted by comparing the intensity of pain among patients who underwent surgery with the Kocher incision technique and the midline incision technique during a 24-hour period.

\section{Population dan Sample}

The population of this study was all patients who were diagnosed with symptomatic cholelithiasis that came to the emergency department, surgery department and patients from other departments of Dr. Moewardi Hospital, Surakarta in October 2018-February 2019.

The sample was calculated using rules of thumb formula with 15 subjects for each group. The inclusions criteria of this study were patients aged 18-65 years. The patients were diagnosed to have symptomatic cholelithiasis based on clinical, laboratory, and radiological tests. The patients also agreed to be part of this study by signing informed consent. Whereas, the exclusions criteria of this study were patients with neuropathy, patients with postoperative complications, and patients with elevated transaminase enzymes and weak kidney function.

\section{Study Variables}

The dependent variable of this study was the definition of pain. The independent variable of this study was laparotomy surgery using the Kocher incision technique and the midline incision technique.

\section{Operational Definition of Variables} The dependent variable of this study was the pain. The pain was a sensory sense and unpleasant emotional experienced due to medical treatment. The pain was measured by the Visual Analogue Scale (VAS) with range 1-10 using an ordinal measurement scale.

The independent variable of this study was laparotomy surgery with Kocher incision technique and midline incision technique. The midline incision implies a vertical incision through the skin, subcutaneous fat, linea alba, and peritoneum in which most of the fibers, crossing the linea alba in a mediocaudal and medio-proximal direction, are cut transversely.

\section{Study Instruments}

The level of pain is measured using VAS scale.

\section{Data Analysis}

Data analysis was statistically measured by using Mann-Whitney.

\section{Research Ethics}

This study had got approval from the ethics committee of the Medical Faculty of UNS/Dr. Moewardi Hospital, Surakarta with number 34 / UN15.5 / KEPK / 2019.

\section{RESULTS}

This study was performed toward 30 patients who were diagnosed to have symptomatic cholelithiasis that came to the emergency room and digestive surgery department of Dr. Moewardi Hospital, Surakarta in October 2018 - February 2019.

Table 1 shows that there were 13 adult patients aged (25-65 years) with Kocher incision (86.7\%) and 11 adult patients with midline incision (73.3\%). Most of the patients with Kocher and midline incision were female. There were 11 female patients with the Kocher incision (73.3\%) and 12 female patients with the midline incision (80.0\%).

Serum transaminase levels of the patients who received paracetamol analgesics with Kocher incision and midline incision were in the normal category. 
Based on the table above, it could be inferred that the characteristics of patients based on age, gender, and transaminase level did not indicate the significant difference or homogenous. Mann-Whitney U test was used to find out the comparison of pain in the Kocher incision and midline incision in postoperative patients with cholecystectomy laparotomy. The results could be seen in table 2 .
Based on table 2, it could be seen that the mean pain score of hemorrhoid patients in the Kocher incision group (Mean=2.33; $\mathrm{SD}=0.72)$ was similar to the mean pain score of midline incision group (Mean=2.20; $\mathrm{SD}=0.79$ ), but they were statistically nonsignificant $(\mathrm{p}=0.192)$.

\section{Table 1. Sample characteristics}

\begin{tabular}{|c|c|c|c|}
\hline \multirow[b]{2}{*}{ Characteristics } & \multicolumn{2}{|c|}{ Incision } & \multirow[b]{2}{*}{ Total } \\
\hline & $\begin{array}{c}\text { Kocher } \\
\text { n (\%) }\end{array}$ & $\begin{array}{c}\text { Midline } \\
\text { n (\%) }\end{array}$ & \\
\hline \multicolumn{4}{|l|}{ Age } \\
\hline Adult & $13(86.7)$ & $11(73 \cdot 3)$ & $30(100.0)$ \\
\hline Elderly & $2(13 \cdot 3)$ & $4(26.7)$ & \\
\hline \multicolumn{4}{|l|}{ Sex Category } \\
\hline Male & $4(26.7)$ & $3(20.0)$ & $30(100.0)$ \\
\hline Female & $11(73 \cdot 3)$ & $12(80.0)$ & \\
\hline \multicolumn{4}{|l|}{ Transaminase } \\
\hline Normal & $15(100.0)$ & $15(100.0)$ & $30(100.0)$ \\
\hline Abnormal & $0(0.0)$ & $\mathrm{o}(0.0)$ & \\
\hline
\end{tabular}

Table 2. Difference test results of pain in the kocher incision and midline incision in postoperative patients with cholecystectomy laparotomy

\begin{tabular}{lccc}
\hline \multicolumn{1}{c}{ Incision } & Mean & SD & p \\
\hline Kocher Incision & 2.33 & 0.72 & 0.192 \\
Midline Incision & 2.20 & 0.79 & \\
\hline
\end{tabular}

\section{DISCUSSION}

The incidence of cholecystitis increased along with age. There was a lack of clear physiological explanation about the increase of cholelithiasis cases among people with a higher age range.

The increase of the incidences among older males was related to the ratio of androgen to estrogen transformation (Parmar et al., 2015). Cholecystectomy is the definitive therapy for patients with symptomatic cholelithiasis, a variety of incision techniques used in cholecystectomy surgery.

There are two incisions which frequently used namely midline incision and oblique incision (Kocher incision). Linea mediana incision is performed when pathological condition occurs such as hiatal hernias or duo- denal ulcers that required surgical considerations. The midline incision perform a vertical incision through the skin, subcutaneous fat, linea alba, and peritoneum. Most of the fibers, crossing the linea alba in a mediocaudal and medio-proximal direction, are cut transversely. The incision is easy to perform and results in minimal blood loss, because of the avascular nature of the linea alba. The incision can be made quickly, it is on average 7-9 minutes. Moreover, the surgical wide view is excellent for some cases. Extensions, when required, could easily be made superiorly or inferiorly, providing access to the whole abdominal cavity, including the retroperitoneum. The midline incision is suitable for emergency and exploratory surgery 
(Goligher et al., 1969; Burger et al., 2002; Kloeters et al., 2016).

There were 9 patients $(60,0 \%)$ with Kocher incision during 24 hours pain intensity with the VAS score of 2 and 6 patients (40,0\%) with midline incision during 24 hours pain intensity with the VAS score of 2. The result of the statistic test showed that there was no significant difference in pain level in the Kocher and midline group $(\mathrm{p}=$ o.192).

Pain is a subjective sensation, the unpleasant feeling associated with actual or potential tissue damage (Leppert, 2009). The pain could also generate mechanical stimuli such as tissue expansion that suppress pain receptors (Taylor, 2007). Postoperative pain is the pain that occurs as a result of actual tissue damage followed by an inflammatory process (Apfelbaum et al., 2003). The pain that occured after cholecystectomy was associated with sensitive areas toward incision wounds. The Kocher incision technique incised many muscular tissue structures so that it was possible to cause a higher pain perception compared to the midline incision technique. However, the statistical test results revealed that there was no significant difference in the level of pain in the Kocher incision group and the midline incision group $(\mathrm{p}=0.192)$. The researcher recommended examining the pain scale score by using other indicators or one person to examine the VAS scale to decrease the bias value and subjectivity.

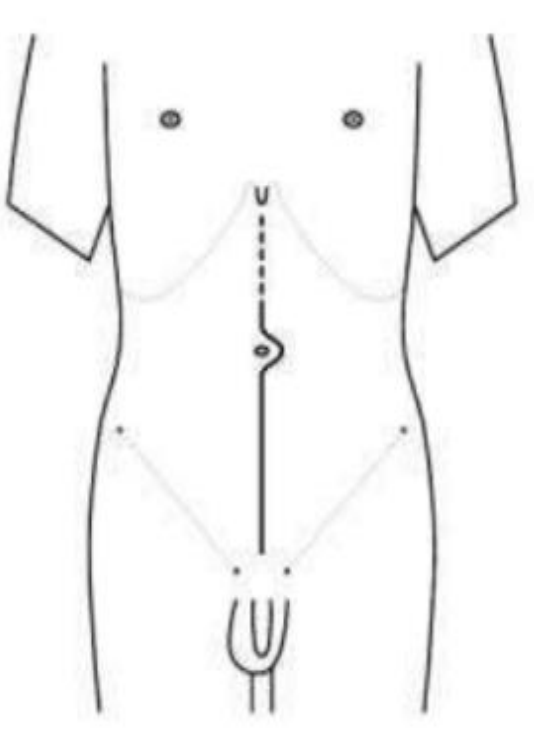

A

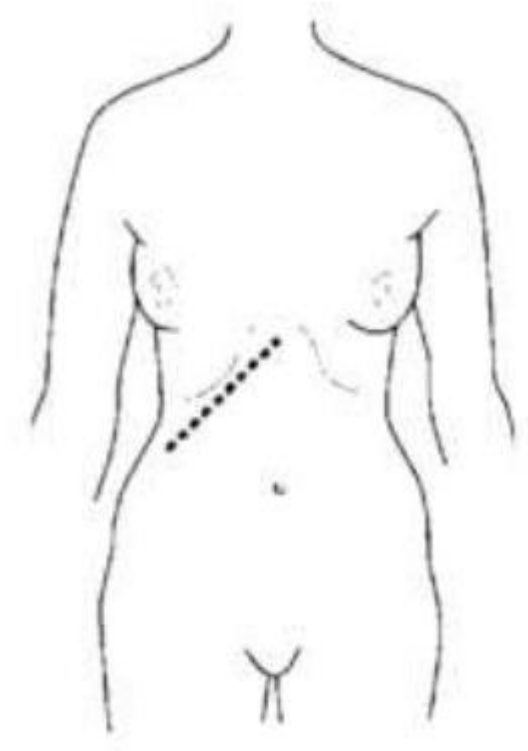

B

\section{Figure 1. Midline Incision (A) and Kocher Incision (B) Source: Keshav et al. (2015)}

Subcostal oblique incision technique (Kocher Incision) had some benefits such as providing a good viewing area, generating more comfortable postoperative injuries, and causing less frequently incisional hernia incidences compared to the midline incision. The subcostal or Kocher incision was an oblique incision that followed the costal margin about $2 \mathrm{~cm}$ below the right arcus costae and was directed in a medio-cranial to below the xiphoid, by making incisions in the tranversus abdominis, rectus abdominis and 
internal oblique abdominis muscles. This technique provided good exposure for biliary and bariatric surgery and could be extended bilaterally if needed. Many segmental blood vessels and nerves were dissected, the duration of the incision and the amount of blood loss were equal to transversal incision (Patnalk, Singla and Bansal, 2001). It was required to assess the incidences of longterm postoperative complications between the two-incision techniques, such as incisional hernia complications, postoperative wound healing, long-term pain incidence rates, and duration of surgery. The researchers suggested postoperative local infiltration anesthesia to reduce the patient's need for consumption of postoperative analgesic drugs.

Based on the result of this study, there is no significant difference in the intensity of pain during 24 hours with the VAS score of 2 between the Kocher and the midline groups.

\section{AUTHOR CONTRIBUTION}

Agus Y, RTH. Supraptomo had some roles in conceptualizing the study, conducting an investigation, and determining methodology. Eka Satrio Putra played a role in writing and editing the scripts.

\section{CONFLICT OF INTEREST}

There was no conflict of interest in this study.

\section{FUNDING AND SPONSORSHIP}

This study used a personal fund.

\section{ACKNOWLEDGEMENT}

We give the best gratitude to the Faculty of Medicine, Universitas Sebelas Maret, Surakarta, and Dr. Moewardi Hospital, Surakarta, who helped to carry out this study.

\section{REFERENCE}

Apfelbaum J, Chen C, Mehta SS, Gan TJ (2003). Postoperative pain experience:
Result from a national survey suggest postoperative pain continues to be undermanaged. Anesth Analg. 97(2): 534-540. https://doi.org/10.1213/o1.ane.ooooo68822.10113.9e.

Burger JWA, van't Riet M, Jeekel J (2002). Abdominal incisions: Techniques and postoperative complications. Scand J Surg, 91: 315-321. Retrieved from: https://journals.sagepub.com/doi/pdf/10.1177/145749690209100401.

Goligher J, Graham NG, De Dombal FT, Giles GR, Clark CG (1969). The value of stretching of anal sphincters in the relief of pain after haemorrhoidectomy. Br J Surg, 56(5): 390. Retrieved from: https://www.ncbi.nlm.nih.gov/pubmed /5781088.

Keshav K, Chahal MS, Joshi HS, Kashmir S, Agarwal R(2015). Prevalece of different types Gallstone in the patient with cholelithiasis at rohilkhan medical college and hospital. Int J Contemp Surg, 3(1): 1-4. http://doi.org/10.5958/2321-1024.2015.00001.X.

Kloeters O, Ulrich DJO, Bloemsma G, van Houdt CIA (2016). Comparison of three different incision techniques in A1 pulley release on scar tissue formation and postoperative rehabilitation. Arch Orthop Trauma Surg. 136: 731-737. https://doi.org/10.1007/s00402-0162430-z.

Leppert W (2009). Tramadol as an analgesic for mild to moderate cancer pain. Pharmacol Rep, 61(6): 978-992. https://doi.org/10.1016/s1734-1140(09)701598.

Parmar A, Parmar AD, Sheffield KM, Adhikari D, Davee RA, Vargas GM, Tamirisa NP, Kuo YF, et al. (2015). PREOP-Gallstones: A prognostic nomogram for the management of symptomatic cholelithiasis in older patients. Ann Surg, 
Supraptomo et al./ Comparison of Pain in the Kocher and Midline Incisions

261(6): 1184-1190. https://doi.org/10.1097/SLA.ooooooooooooo868.

Patnaik VV, Singla RK, Bansal V (2001).

Surgical incisions-Their anatomical basis part IV-abdomen. J Anat. Soc. In- dia, 50(2): 170-178. Retrieved from: http://medind.nic.in/jae/to1/i2/jaeto1i 2p170.pdf.

Taylor P (2007) Principle of Pain: Principle of Medical Pharmacology. 7 th edn. Canada: Elsevier. 